\title{
A Systems Approach to Social Entrepreneurship
}

\section{De Ruysscher, C. Claes, T. Lee, F. Cui, J. Van Loon, J. De Maeyer \& R. Schalock}

VOLUNTAS: International Journal of Voluntary and Nonprofit Organizations

Official journal of the International Society for Third-Sector Research

ISSN 0957-8765

Voluntas

DOI 10.1007/s11266-016-9704-5

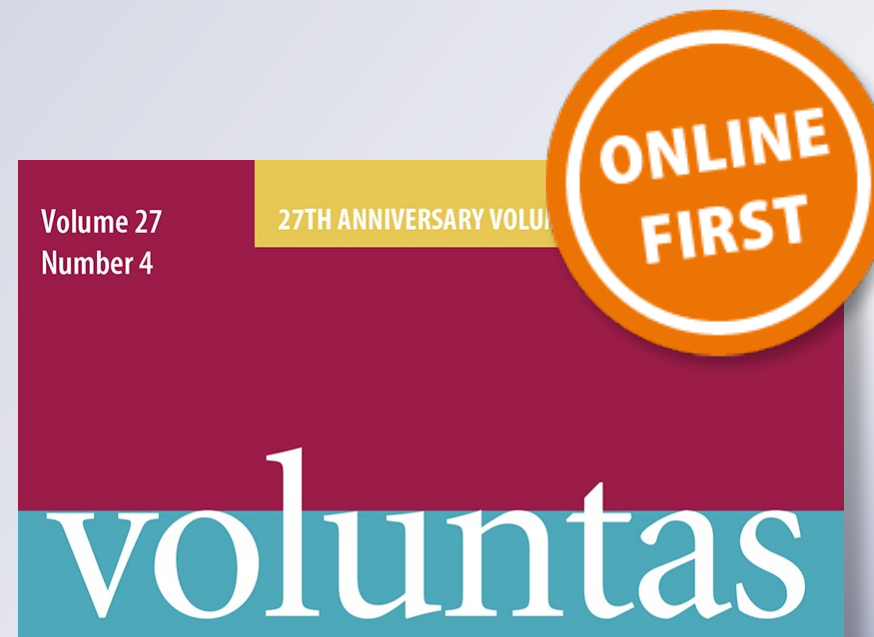

International Journal of Voluntary and Nonprofit Organizations

\section{I $\mathbf{S} \mathbf{T} \mathbf{R}$ INIERNATIONAL SOCIITY For}

Springer

$11266 \cdot$ ISSN $0957-8765$

$27(4) 1515-2010(2016)$ 
Your article is protected by copyright and all rights are held exclusively by International Society for Third-Sector Research and The Johns Hopkins University. This e-offprint is for personal use only and shall not be selfarchived in electronic repositories. If you wish to self-archive your article, please use the accepted manuscript version for posting on your own website. You may further deposit the accepted manuscript version in any repository, provided it is only made publicly available 12 months after official publication or later and provided acknowledgement is given to the original source of publication and a link is inserted to the published article on Springer's website. The link must be accompanied by the following text: "The final publication is available at link.springer.com". 


\title{
A Systems Approach to Social Entrepreneurship
}

\author{
C. De Ruysscher ${ }^{1}$ - C. Claes ${ }^{1} \cdot$ T. Lee ${ }^{2}$. \\ F. Cui ${ }^{3} \cdot$ J. Van Loon ${ }^{4} \cdot$ J. De Maeyer ${ }^{1}$. \\ R. Schalock ${ }^{5}$
}

(C) International Society for Third-Sector Research and The Johns Hopkins University 2016

\begin{abstract}
Currently, disabilities organizations are increasingly being challenged by the requirement for individualized service, expectations to show personal outcomes, and the need to base their services on evidence-based practices. Social entrepreneurship (SE) is being put forward as an innovative approach for dealing with these challenges. This article presents a systems approach to SE based on a program logic model. This model identifies the input factors (a strong social vision, exploiting opportunities, maximizing resources), throughput strategies (entrepreneurial orientation, critical thinking skills, networking, capacity building), and
\end{abstract}

C. De Ruysscher

clara.deruysscher@ugent.be

C. Claes

claudia.claes@hogent.be

T. Lee

tim.lee@vtcidd.org

F. Cui

fcui@law.harvard.edu

J. Van Loon

jloon@arduin.nl

J. De Maeyer

jessica.demaeyer@hogent.be

R. Schalock

rschalock@ultraplix.com

1 Faculty of Education Health and Social Work, University College Ghent, Valentin

Vaerwyckweg 1, 9000 Ghent, Belgium

2 Vocational Training Center, Taipei, Taiwan

3 One Plus One Group for Disability, Xiluoyuan 2 Qu, Building \#22, Room 604, Fengtai District, Beijing 100077, China 
outcome components (improving people's lives, community-building, improving society) of SE at the micro, meso, and macro level. Also, the importance of planning for contextual changes as a social entrepreneur is discussed. The article concludes with presenting three inspiring practices regarding SE in the field of disabilities organizations.

Résumé À l'heure actuelle, les organisations de handicapés sont de plus en plus confrontées à l'exigence d'un service personnalisé, aux attentes pour afficher les résultats personnels et à la nécessité de fonder leurs services sur des pratiques fondées sur des données probantes. L'entrepreneuriat social est présenté comme une approche novatrice pour faire face à ces défis. Cet article présente une approche systémique de l'entrepreneuriat social basée sur un modèle logique de programme. Ce modèle identifie les facteurs d'entrée de l'entrepreneuriat social (une vision sociale forte, la recherche de débouchés, l'optimisation des ressources), les stratégies de rendement (l'orientation entrepreneuriale, la pensée critique, la mise en réseau, le renforcement des capacités) et les éléments des résultats (l'amélioration des conditions de vie des populations, le renforcement de la communauté, l'amélioration de la société) aux niveaux macroéconomique, méso-économique et microéconomique. L'importance de la planification des changements contextuels en tant qu'entrepreneur social est également traitée. L'article se termine par la présentation de trois pratiques enrichissantes concernant l'entrepreneuriat social dans le domaine des organisations de handicapés.

Zusammenfassung Ein gegenwärtig wachsendes Problem für Behindertenorganisationen sind das Erfordernis für individualisierte Dienstleistungen, die Erwartungen, persönliche Resultate nachzuweisen und die Notwendigkeit, ihre Dienstleistungen auf bewährte Praktiken zu basieren. Das soziale Unternehmertum steht dabei als ein innovativer Ansatz zum Umgang mit diesen Herausforderungen im Vordergrund. Dieser Beitrag präsentiert einen Systemansatz zum sozialen Unternehmertum beruhend auf einem Programmlogik-Modell. Dieses Modell identifiziert die Inputfaktoren (eine starke soziale Vision, Chancennutzung, Ressourcenmaximierung), Durchsatzstrategien (unternehmerische Orientierung, kritisches Denken, Networking, Kapazitätsbildung) und Ergebniskomponenten (Verbesserung des Lebens einzelner Personen, Gemeinschaftsbildung, Verbesserung der Gesellschaft) des sozialen Unternehmertums auf der Mikro-, Meso- und Makroebene. Zudem wird die Bedeutung einer Planung für Kontextänderungen für soziale Unternehmer diskutiert. Abschließend präsentiert der Beitrag drei anregende Praktiken im Hinblick auf das soziale Unternehmertum im Bereich der Behindertenorganisationen.

Resumen Actualmente, las organizaciones de discapacitados cada vez se ven más cuestionadas por el requisito de un servicio individualizado, expectativas para

4 Arduin Foundation, Seissingel 4, 4333 GV Middelburg, The Netherlands

5 Department of Psychology, Hastings College, PO Box 285 2435, Cottonwood Creek Road, Chewelah, WA 99109, USA 
mostrar resultados personales y la necesidad de basar sus servicios en prácticas basadas en la evidencia. El emprendimiento social (SE, por sus siglas en inglés) se presenta como un enfoque innovador para tratar estos desafíos. Este artículo presenta un enfoque de sistemas del emprendimiento social basado en un modelo lógico de programas. Este modelo identifica los factores de entrada (una potente visión social, explotación de oportunidades, maximización de recursos), las estrategias de rendimiento (orientación empresarial, habilidades de pensamiento crítico, trabajo en red, creación de capacidad) y los componentes del resultado (mejora de las vidas de las personas, construcción de la comunidad, mejora de la sociedad) del SE a nivel micro, medio y macro. Asimismo, se trata la importancia de la planificación de cambios contextuales como un emprendedor social. El artículo concluye presentando tres prácticas inspiradoras relativas al SE en el campo de las organizaciones de discapacitados.

Keywords Social entrepreneurship - Disabilities organizations · Program logic model

\section{Introduction and Overview}

Not-for-profit organizations providing services and supports to persons with disabilities are increasingly expected to be more efficient and effective in the outcomes they achieve and the resources they use. This requires that they think outside the traditional ways of funding and providing services and supports, and transform their service-delivery system into one that is customer-centered, community-based, sustainable, and responsive to the needs of diverse populations (Kidd and McKenzie 2013; Schalock and Verdugo 2012a, b). As discussed in the present article, this shift in thinking is best exemplified in the concept of social entrepreneurship (SE) which we define as "a systematic process that aims to create social value at three levels: improving people's lives, community-building, and improving society. It is facilitated by a strong social vision, the capacity to exploit opportunities and to maximize resources, using strategies based on an entrepreneurial orientation, critical thinking skills, networking, and capacity building". This definition is based on the work of Gray et al. (2003), Mair and Marti (2006), Kidd and McKenzie (2013), Kumar and Gupta (2013), Light (2005), Lumpkin et al. (2013), Peredo and McLean (2006), and Roberts and Woods (2005).

Although it is a promising and emergent approach for dealing with these challenges and complex social needs, the concept of social entrepreneurship is still variably defined and its boundaries remain fuzzy (Mair and Marti 2006). The purpose of this article is to build on our current understanding of social entrepreneurship and to clarify the phenomenon by describing a comprehensive model of social entrepreneurship, including its components and application. In this article, we focus on: (a) a conceptual model of SE, (b) a systems approach to SE, (c) the importance of planning for contextual changes, (d) inspiring practices in the field of disabilities organizations, and (e) future directions in the field of SE. 


\section{A Conceptual Model of Social Entrepreneurship}

As an overview to the conceptual model presented as Fig. 2, it is important for disabilities organizations to have insight into the input, throughput, and output components and the critical indicators of their service-delivery system. These components and indicators can be represented in a program logic model such as that in Fig. 1. To this end, a program logic model shows the interconnectedness of the input-throughput-output process at the micro, meso, and macro level of an organization (Schalock and Verdugo 2012a; Bronfenbrenner 1992; Funnell and Rogers 2011; Isaacs et al. 2009). In doing so, it provides insight into the alignment between system-level processes and organization-level practices (vertical alignment) and the alignment between the organization's input, throughput, and output components (horizontal alignment) (Schalock et al. 2008; Schalock and Verdugo 2012a, b, 2013).

Frequently there is a tension between individual support needs at the micro level and the ability for organizations (the meso level) to provide supports that are both individualized and reduce the discrepancy between the individual's capabilities and the demands of his/her environment. This tension confronts disabilities organizations with a double challenge. First, the current scarcity of resources and money-saving regulations (the macro level) challenge organizations to fulfill program recipients' support needs. Second, service/support users are encouraged to adopt the attitude of accepting less than optimal. On top of that, many organizations are faced with long waiting lists. This double challenge affects and shapes the organization's capacity.

$\mathrm{SE}$ is increasingly suggested as an innovative approach for dealing with these challenges. SE operates at the center of the above-mentioned process and is housed at the intersection of the mesosystem and the throughput systems component, as is depicted in the conceptual model depicted (Fig. 2). Because of its central position, SE has an important bridging function at several levels. First, it bridges between the macro and the micro level. Often, social entrepreneurs are capable of getting around

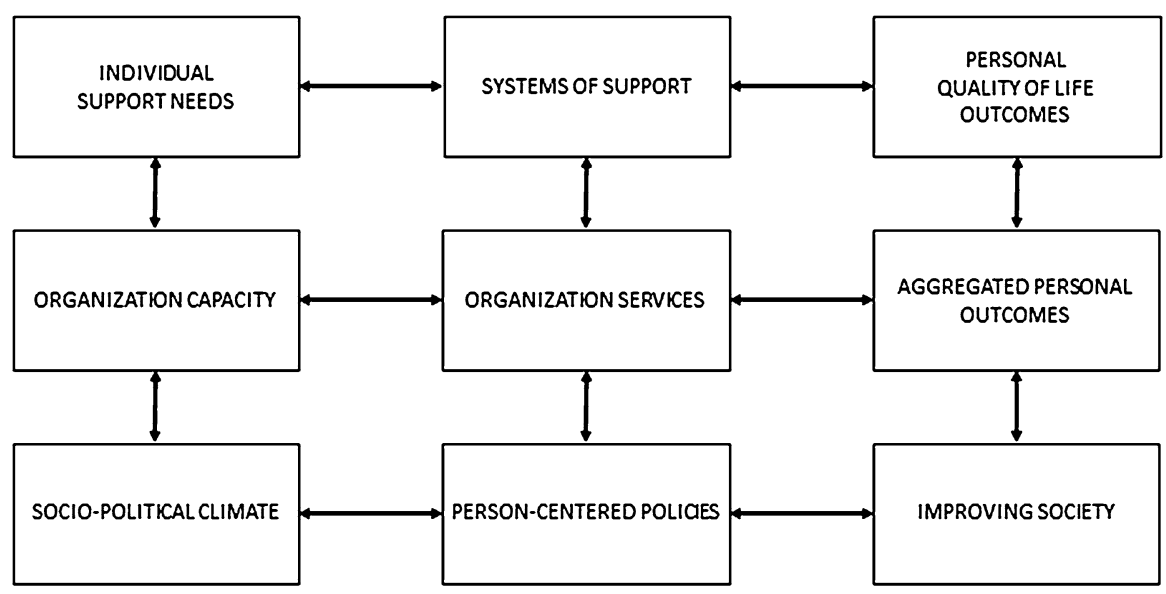

Fig. 1 A program logic model 


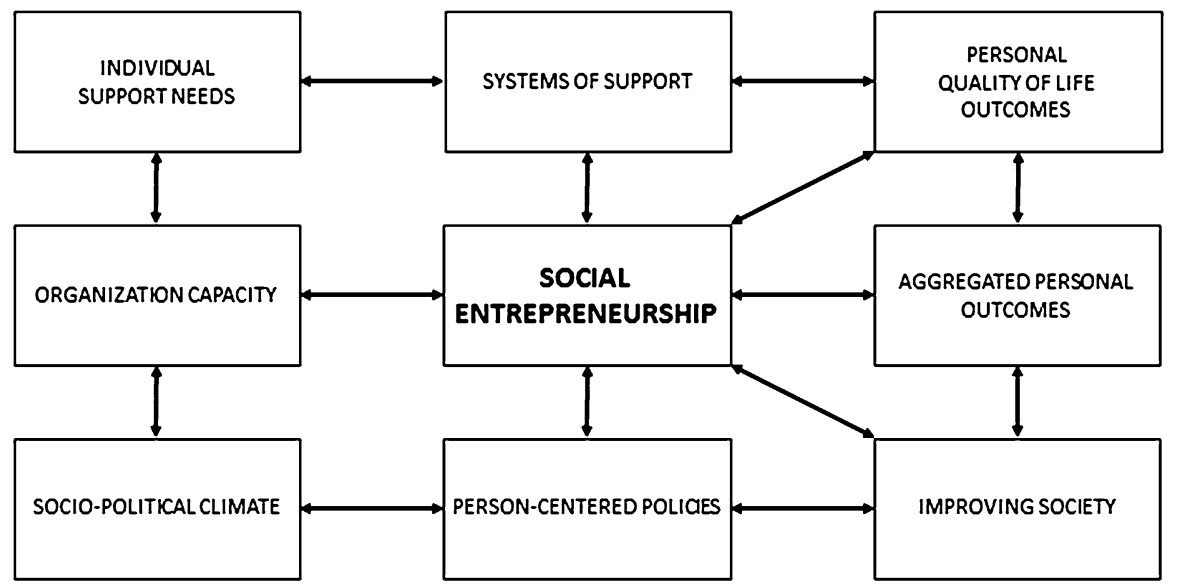

Fig. 2 A conceptual model of social entrepreneurship

institutional barriers and even influence policy decisions at the macro level in order to realize adequate support (Desa 2011; Di Domenico et al. 2010; Montgomery et al. 2012). Also, SE creates links between organizations and stimulates collaboration and community-building across the boundaries of different sectors. This collaborative action is necessary to gain support and legitimacy in the community and provides cultural and social diversity (Montgomery et al. 2012). And most importantly, SE has become an indispensable bridge towards a higher quality of life for people with disabilities (Thake and Zadek 1997).

\section{A Systems Approach to Social Entrepreneurship}

A systems approach to SE starts with a logic model that is used to both explain the phenomenon and to provide the framework for its implementation (Isaacs et al. 2009). The logic model presented in Fig. 3 summarizes the input, throughput, and outcome components of our model. As depicted in Fig. 3, the input component involves having a strong social vision, exploiting opportunities, and maximizing resources (Dees 1998; Johnson 2000); the throughput component involves SE strategies involving an entrepreneurial orientation, critical thinking skills, networking, and capacity building; and the outcome component includes creating social value at the micro-, meso-, and macro-system levels (Mair and Marti 2006; Peredo and McLean 2006).

\section{Input Factors}

\section{A Strong Social Vision}

There is broad agreement that social entrepreneurs and SE are driven by values and social goals that benefit individuals, organizations, and society (Peredo and McLean 


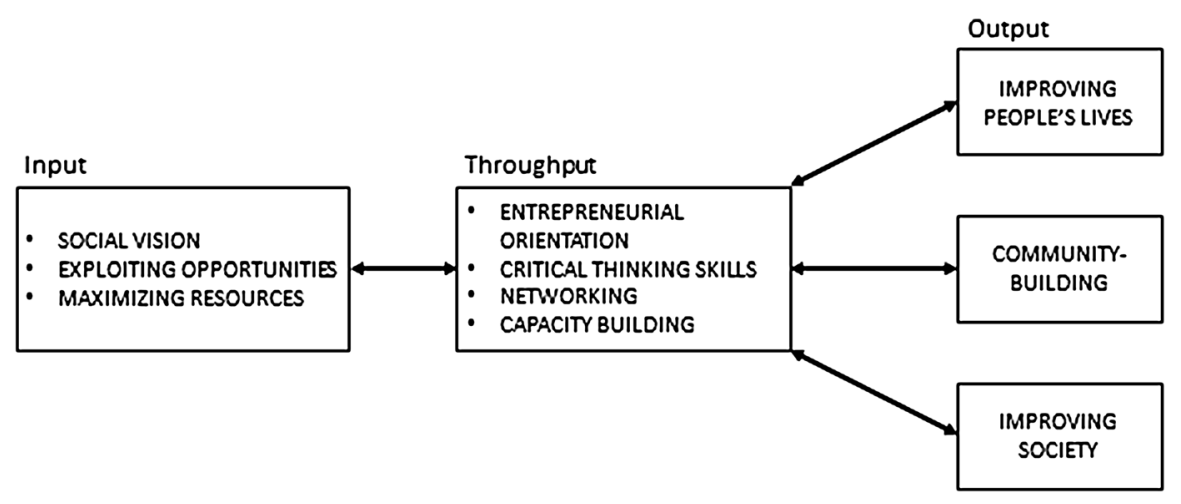

Fig. 3 A logic model of social entrepreneurship

2006). Values form the vision and culture of an organization and include dignity, equality empowerment, self-direction, nondiscrimination, inclusion, and focus on improving people's lives, the community, and society (Kidd and McKenzie 2013; Peredo and McLean 2006).

\section{Exploiting Opportunities}

Characteristic to social entrepreneurship is a shift in perceptions towards seeing social ills and social problems as opportunities, and to see entrepreneurship as a source of solutions (Light, 2005; Lumpkin et al. 2013). In other words, each of the challenges mentioned in the Introduction can be viewed as an opportunity to 'do things differently'. However, for an opportunity to become a SE strategy, it is generally necessary to plan for contextual changes in larger service-delivery systems. Therefore, social entrepreneurs need to understand the context of their organization and realize that there is frequent resistance to change that occurs around changing current rules and regulations and developing new practices.

\section{Maximizing Resources}

SE also builds on resources, but an expanded conception of what resources are. As discussed by Schalock and Verdugo (2012a, b, 2013), resources need to be thought of as something more than financial capital. Indeed, resources include time, expertise, tacit knowledge, and explicit knowledge.

\section{Throughput Strategies}

\section{Entrepreneurial Orientation}

Social entrepreneurs feel the need to be proactive and innovative, taking into account an above average degree of risk. Employing an entrepreneurial orientation often results in the creation of a social enterprise, which encompasses a values- 
based project, a business organization, or a systematic purposeful activity (Lumpkin et al. 2013; Peredo and McLean 2006; Roberts and Woods 2005).

\section{Critical Thinking Skills}

Innovation and creativity require critical thinking skills related to divergent thinking (i.e., standing outside the box and viewing things differently, alignment and systems thinking). Alignment forces entrepreneurs to think logically and place or bring services and supports delivery processes into a logical input, throughput, and output sequence. Systems thinking focuses on the multiple factors that affect human functioning at the micro-, meso-, and macro-system levels (Schalock et al. 2014).

Networking involves partnering through networks composed of local actors, stakeholders, for-profit organizations, not-for-profit organizations, and public entities. In doing so, social entrepreneurial organizations are strongly embedded in their community and able to provide a practice-based response to problems in their community, because their solutions are built on local knowledge and experience, shared values, common goals, and a sense of belonging (Kidd and McKenzie 2013; Peredo and Chrisman 2006; Peredo and McLean 2006).

\section{Capacity Building}

Organizational capacity is the critical toolkit that encompasses the knowledge, systems, and processes that contribute to organizational effectiveness (Kapucu et al. 2011; Linnell 2003). Capacity building involves designing and implementing activities related to enhancing the organization's effectiveness and efficiency in terms of services/supports delivery, resource development, and research and evaluation (International Research Consortium on Evidence-Based Practice 2013; Schalock et al. 2014).

\section{Valued Social Outcomes}

As Glenn (2014) states, "it is unreasonable to expect societies to cooperatively create and implement strategies to build a better future without some general agreement about what that desirable future is" (p.20). In other words, creating social value needs to be defined operationally in reference to outcomes at three levels. At the micro-system level (i.e., the individual), social value is defined as improving people's lives in reference to valued personal outcomes such as human functioning and/or quality of life domains. At the mesosystem level (i.e., the organization and community), social value is defined in terms of organization and/or community-building. Community-building is defined by Weil (1996) as "activities, practices, and politics that support and foster positive connections among individuals, groups, organizations, neighborhoods, and geographic and functional communities". At the macro-system level (i.e., societal), creating social value is defined in terms of improving society as reflected in indices reflecting socioeconomic status, positive health, environmental quality, and subjective well-being. 
Table 1 Measurable indicators of valued social outcomes

\begin{tabular}{ll}
\hline Outcome category & Measurable indicators \\
\hline $\begin{array}{c}\text { Improving peoples' lives (individual } \\
\text { and family quality of life) }\end{array}$ & $\begin{array}{c}\text { Individual referenced quality of life domains: personal } \\
\text { development, self-determination, interpersonal relations, } \\
\text { social inclusion, rights, emotional well-being, physical well- } \\
\text { being, material well-being } \\
\text { Family referenced quality of life domains: family interactions, } \\
\text { parenting, emotional well-being, personal development, } \\
\text { physical well-being, financial well-being, community } \\
\text { involvement, disability-related supports } \\
\text { Social capital networks } \\
\text { Norms of reciprocity and trust } \\
\text { Inclusion and community involvement } \\
\text { Mutual support systems ('circles of supports') } \\
\text { Community ties/affiliation } \\
\text { Socio-economic position (education, occupation, income) } \\
\text { Health (longevity, wellness, access to health care) } \\
\text { Environmental quality (air, water, green space) } \\
\text { Subjective well-being (life satisfaction, positive affect } \\
\text { (happiness, contentment), absence of negative affect } \\
\text { (sadness/worry, helplessness) }\end{array}$ \\
&
\end{tabular}

Table 1 provides an overview of the how 'creating social value' is defined operationally in terms of measurable indicators related to improving peoples' lives, community-building, and improving society. The quality of life outcomes listed in Table 1 are based on the published work of Brown et al. (2013), Chiu et al. (2013), Claes et al. (2010, 2012), Felce and Perry (1995), Petry et al. (2005), Schalock et al. (2007), Schalock and Verdugo (2012a, b), and Zuna et al. (2010). Those outcomes associated with community-building are based on the published work of Adler and Kwan (2002), Putnam et al. (2004), and Stone (2003). Those outcomes associated with improving society are based on the published work of Brown et al. (2013), Burchardt (2008), Emerson et al. (2006), and Snell and Luckasson (2009).

Besides being a mediator between the input, throughput, and output components of the logic model (horizontal alignment), social entrepreneurship also has an important bridging function between the micro-, meso-, and macro-system levels (vertical alignment). This alignment is depicted in Fig. 4. For example, when certain policy-level decisions (at the macro level) hinder the implementation of desirable systems of support for a person with a disability (at the micro level), social entrepreneurship can find innovative ways to influence policy makers to adjust their regulations. In other words, social entrepreneurship fulfills an important moderating and conciliatory function between the micro- and macrosystem levels. 
Fig. 4 Vertical alignment of social entrepreneurship

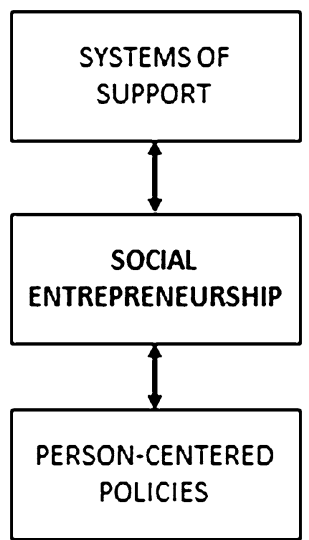

\section{Planning for Contextual Changes}

SE does not occur in a vacuum. The interaction between the social entrepreneur and the context is indispensable. To be most effective, social entrepreneurs need to recognize that planning for contextual changes is equally important as planning for changes in practices. The context within which not-for-profit agencies operate frequently generates resistance to change that occurs around new practices (Manchester et al. 2014). Many of the contextual issues causing resistance to change can be viewed from the perspective of mental models that are deeply ingrained assumptions, generalizations, and images used to understand the world and form the vision and culture of an organization, service-delivery system, or society (Schalock and Verdugo 2012b). Examples from the disability field include: (a) an emphasis on defectology, segregation, and control in reference to persons with disabilities; and (b) a focus on organizations as mechanistic entities that need to be highly regulated, as opposed to organizations as self-evaluating and improving systems. Other contextual issues causing resistance to change involve societal attitudes towards—and approaches to — persons with disabilities, and outdated, but still operational, rules and regulations.

Social entrepreneurs need to analyze their context for such inhibiting factors. Since SE is housed at the intersection of the mesosystem and the throughput systems component of the logic model (cf. Fig. 2), social entrepreneurs find themselves in a central position to conduct a critical exploration of all the contextual factors related to their organization. This is important, because inhibiting factors can be found in all horizontal (input, throughput, output) and vertical (micro, meso, macro) components of the model. In this respect, it can be helpful to apply a mechanism for change, that focuses on five factors involved in the 'unfreezing' and change process, and uses the input, throughput, and output components of a program logic model to organize the analysis. The five factors involved in the 'unfreezing' process are: (a) identifying contextual factors that hinder change, (b) conducting a discrepancy analysis that identifies the 'disconnects' between where one is and where one wants to be, (c) identifying the forces for change that will increase momentum and 


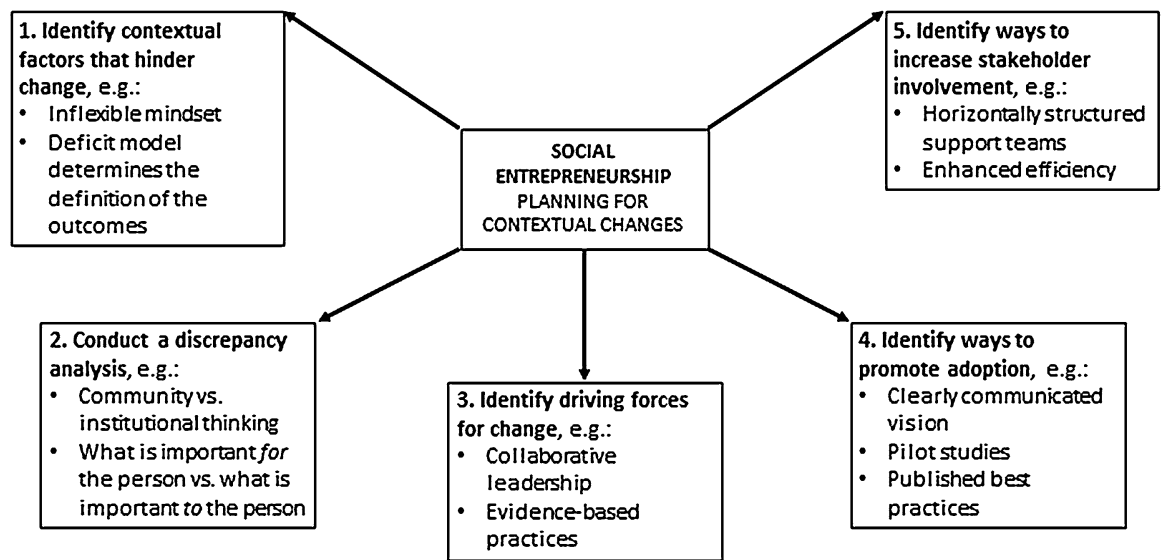

Fig. 5 Contextual analysis as a mechanism for change

receptivity, (d) identifying ways to promote adoption, and (e) identifying ways to increase stakeholder participation (Lewin 1951; Manchester et al. 2014; Schalock and Verdugo 2012a).

Figure 5 provides an illustration of such a contextual analysis. It summarizes the results of an extensive contextual analysis completed recently by the Consortium on Community Living in Taiwan (Lee, personal correspondence). Once the contextual analysis is completed, an action plan can be developed around specific cells within the contextual analysis matrix.

\section{Exemplary Social Entrepreneurial Practices}

SE flourishes best in the interaction between the dynamics at the micro, meso, and macro levels. It is a process that can be compared with improvisational theater. The only given at the start of the performance is the décor and a group of actors that embark on a creative journey as they take on several roles in order to build up to the moral of the story. Inherent to improvisation is the unpredictability of many possible storylines building up to the same moral. Just like improvisational theater, there is no standard recipe for social entrepreneurship. Once an innovative idea is created, social entrepreneurs embark on a creative journey in search of resources, stakeholders, and strategies that help putting their ideas into practice (Di Domenico et al. 2010). However promising, this daring and creative aspect of SE still raises questions among disabilities organizations, policy makers, and practitioners who prefer the safety of top-down regulations and funding.

$\mathrm{SE}$ is not a new phenomenon in not-for-profit organizations. Many such organizations were founded by pioneers who managed to turn a strong social vision into reality, starting with little financial and social capital. In other words, social entrepreneurship is as old as the sector itself. There is a wealth of tacit knowledge available in organizations who are explicitly or implicitly involved in social 
entrepreneurial processes. Therefore, it is inspirational to take a closer look at three organizations (BOSKE Bakery Café, One Plus One and Arduin) who apply social entrepreneurial strategies in order to create social value.

\section{BOSKE Bakery Café (Taiwan)}

Qi Zhi Vocational Training Center is a social services organization that provides community living and vocational rehabilitation services to adults with intellectual and developmental disabilities (IDD). The first café was established in 2002. A central bakery was added in 2006. Currently, there are three café locations and a recently expanded central bakery, employing 35 individuals with disabilities. The everyday practice of these cafés is built around three central operating principles: having a social business, being market competitive, and having a positive image.

\section{Social Business}

BOSKE Bakery Café has operated as a social business from the very beginning. A social business is seen as a double bottom line enterprise, aiming for both financial and social profit, combining the effectiveness and the efficiency of the business mindset with the values and mission of not-for-profit organizations. BOSKE is built on a business model that strives for an efficient and effective operation, resulting in a self-sustaining business, independent of government funding or charitable donations. Therefore, BOSKE has a greater potential to provide long-term benefits to individual employees and to have an impact on the larger society.

\section{Market Competitive}

In order to be a self-sustaining social business, BOSKE's products and services have to be market competitive. A lot had to be learned about product segmentation, target customers, value proposition, and many other business strategy concepts to compete with other bakery and café businesses. The general aim of BOSKE is that people buy their products because they love the baked goods and services, rather than people buying products out of a sense of pity, compassion, or duty. This insistence forces BOSKE to strive for quality and efficiency and show the larger society that individuals with different life challenges can and do bring great value to the society.

\section{Positive Image}

BOSKE aims to inspire people to see individuals with disabilities in a different and positive way. The restaurant experience is designed so that customers are drawn by the products and environment first. As they enjoy the shopping and dining experience, subtle cues are positioned to help them discover the more significant social purpose of BOSKE. Many customers frequent BOSKE for months before realizing that all the products and services are provided by individuals with disabilities. They are all pleasantly surprised by their discovery, and are left with a positive impression of the staff members. Such a positive portrayal both changes the 
society's attitudes and strengthens the value proposition of BOSKE as a business, earning strong customer loyalty to our brand and products.

The bakery cafés creates social value in several ways. First, they aim at enhancing personal quality of life. Having a meaningful and productive job is a major driver for a person's happiness. Many of BOSKE's employees experience significant improvement in their quality of life as a direct result of working in the central bakery or café. They wear their baker's uniform with pride. They show off their freshly baked breads with big smiles on their faces. They interact with customers with ease. One can readily observe clear gains in areas such as job skills, relational connectedness, and economic position. What is even more significant is that many of the individuals working in BOSKE do not qualify for government's vocational programs. The social business model is able to serve those not served by the system. Second, BOSKE aims at creating a greater connection with the larger community on multiple levels. On the individual level, café employees connect with customers and suppliers on a daily basis. On the meso level, partnerships are established with other like-minded businesses. Also, it is possible to gain entry and establish connections with traditional for-profit businesses through their need to implement their corporate social responsibility programs. Also, BOSKE as a social business connects with other agencies and governmental departments, for synergistic partnership and mutual sharpening. A social enterprise approach forces BOSKE to think in ways that integrate the strengths of business and not-for-profit models, and innovate something new that brings social change. It forces not-forprofit agencies to consider the effectiveness and efficiencies of a business mindset. It also forces business operators to consider the importance of creating social value. Social and financial bottom lines are no longer mutually exclusive. Instead, they are equally vital and both obtainable.

\section{One Plus One (Mainland China)}

One Plus One Beijing Cultural Exchange Center for Persons with Disabilities was founded as one of earliest not-for-profit social disabilities organizations in China in 2006 by a group of eight persons with disabilities. Currently, the organization has sections in Beijing and Shanghai, and there are 34 employees: 19 of them have disabilities, including hearing, intellectual, visual, and physical disabilities. Reflecting the potential of social entrepreneurship, the organization has evolved from a media center to a multi-functional social organization, functioning as a platform for persons with disabilities to realize their life goals and values and for all stakeholders to work together for rights advocacy, training, and public education. Their activities include having a radio program, a magazine, a research team, a community service center, and a culture exchange center.

In the past eight years, the development of One Plus One indicated the typical growth of disabled persons' organizations in China (DPOs) to change the way the general public perceives disabilities and to promote social inclusion. During the process of development, members in this group have experienced huge systematic barriers, such as a lack of support from the government as part of civil society, financial challenges, and disassociation with other groups. When they began to 
broadcast radio programs, for example, they realized that the main problem was not to show what persons with disabilities could do, but rather to show society that persons with disabilities could be accepted as equal human beings and could be given opportunities to participate as equal members of society. Meanwhile, the United Nations Convention on the Rights of Persons with Disabilities (CRPD) functioned as a driving force to raise awareness, address attitudinal and social barriers, empower persons with disabilities and their representative organizations, and require a support network for inclusion.

International and professional support interwoven with local rich experience and wisdom of DPOs initiated a transformational period of development for One Plus One to not only work within the disabilities community, but also to realize the critical need to reach out to other groups, such as parent organizations, public interest law firms, and universities in order to create a multidimensional network and joint efforts. Through collaborating with partners at both local and international levels, One Plus One conducted a series of projects, including creating handbooks in plain and simple language on CRPD and Chinese laws and policies, collecting and publicizing narratives of persons with disabilities. These narratives are important and powerful means to address discrimination and prejudices, to train staff members to be advocates of disability rights, to bring stakeholders together, and to stimulate them to work together on sustainable projects.

\section{Arduin (The Netherlands)}

Arduin is a Dutch organization that provides services and supports to 800 people with intellectual disability, in living, work and/or daily activities. Fifteen years ago, Arduin shifted away from a facility-centered organization to a service-delivery center and a community-based approach starting from a quality of life framework (Van Loon and Van Hove 2001). By focusing on quality of life instead of quality of care, the emphasis is on personal outcomes and on identifying the processes needed on an organizational level to enhance these outcomes.

According to Linnell (2003), capacity building is a critical toolkit that enables not-for-profit organizations to operate effectively under uncertain and dynamic circumstances (Kapucu et al. 2011). The literature of capacity building forces us to look outside the box and introduces innovative terms such as field-building work, peer learning groups, social capital, collaborative partnerships, and group workshops (Linnell 2003; Kapucu et al. 2011). Eisinger (2002) refers to capacity as "the resources, effective leadership, skill and sufficient staff, a certain level of institutionalization, and links to the larger community from which an organization might draw help" (p. 117). Arduin embraces capacity building in its broad sense at different levels of the organization. In its consequential policy of focusing on quality of life and supports, it was often necessary to think creatively. For example, because of the expanding costs of transport, Arduin once started its own taxi company to reduce the costs of buying cars (a taxi company has lower taxes when buying a car). There are no problems, only challenges.

As an organizational unit, Arduin moved away from a typical hierarchical organization in which a lot of energy is being put on vertical structures and 
arrangements. Important for the embedding of the concept of quality of life in an organization is the involvement of consumers (Schalock et al. 2007). In other words, it is essential to give meaningful roles to the consumers of the organization. An important question in this respect is the following: to what degree are consumers involved in the development and implementation of their individual supports plan? In order to meet this demand, Arduin developed an Individualized Supports System. As the outcomes of an individual supports plan for a person should be an enhanced quality of life, determining whether this outcome occurs requires the reliable and valid assessment of quality of life-related domains. The Personal Outcomes Scale (POS), which is based on the conceptual quality of life model and measurement framework by Schalock et al. (2002), was developed for that purpose. A POS interview results in scores for the eight quality of life domains that are specified in the model of Schalock et al. (2002).

\section{Future Directions}

This article describes how SE is an innovative catalyst for making change happen at the level of the individual (micro), the organizational level (meso), and society (macro). By developing a conceptual and comprehensive model, based on a program logic model, we aimed to create conceptual clarity and to facilitate the implementation of SE in the daily practice of disabilities organizations.

However, in order to transform these models into tools that can be applied in daily practice, they need to be further operationalized. This can be done in two ways. Firstly, SE is a process that is propelled by inspiration. Therefore, more inspirational practices need to be identified in order to inspire other individuals, organizations, and societies to join in and to stimulate collaboration across the boundaries of sectors. Secondly, a toolkit needs to be developed to support not-forprofit organizations in their social entrepreneurial process. In this respect, it could be helpful to establish Communities of Practice, which consist of actors from both the micro, meso, and macro level (e.g., persons with disabilities, professionals, policy makers, actors from for-profit organizations), in order to ensure that the voices of all actors are taken into account in the development of such a toolkit (Sterk et al. 2013).

A major characteristic of SE is that it evolves from small events, obstacles, and changes that persons and organizations deal with in a creative and innovative way. By bringing together local expertise and creating networks in which these creative solutions can be shared, people become co-owner of the learning processes taking place. This connectedness, we believe, forms the key to success for SE.

\section{References}

Adler, P. S., \& Kwan, S. W. (2002). Social capital: Prospects for a new concept. Academy of Management Review, 27, 17-40.

Bronfenbrenner, U. (1992). Ecological systems theory. London: Jessica Kingsley Publishers.

Brown, I., Hatton, C., \& Emerson, E. (2013). Quality of life indicators for individuals and families with intellectual disabilities: Extending current practice. Intellectual and Developmental Disabilities, 51, 316-332. 
Burchardt, T. (2008). Monitoring inequality: Putting the capacities approach to work. In G. Craig, T. Burchardt, \& D. Gordon (Eds.), Social justice and public policy (pp. 205-229). Bristol: Policy Press.

Chiu, C., Kyzar, K., Zuna, N., Turnbull, A., Summers, J. A., \& Gomez, V. A. (2013). Family quality of life. In M. Wehmeyer (Ed.), The Oxford handbook of positive psychology and disability (pp. 365-392). New York: Oxford University Press.

Claes, C., van Hove, G., Vandevelde, S., van Loon, J., \& Schalock, R. L. (2012). The influence of support strategies, environmental factors, and client characteristics on quality of life-related outcomes. Research in Developmental Disabilities, 33, 96-103.

Claes, C., van Hove, G., van Loon, J., Vandevelde, S., \& Schalock, R. L. (2010). Quality of life measurement in the field of intellectual disability: Eight principles for assessing quality of liferelated outcomes. Social Indicators Research, 98, 61-75.

Dees, J. G. (1998). The meaning of "social entrepreneurship". Draft Report for the Kauffman Center for Entrepreneurial Leadership. California: Stanford University.

Desa, G. (2011). Resource mobilization in international social entrepreneurship: Bricolage as a mechanism of institutional transformation. Entrepreneurship Theory and Practice, 36(4), 727-751.

Di Domenico, M. L., Haugh, H., \& Tracey, P. (2010). Social bricolage: Theorizing social value creation in social enterprises. Entrepreneurship Theory and Practice, 34(4), 681-703.

Eisinger, P. (2002). Organizational capacity and organizational effectiveness among street-level food assistance programs. Nonprofit and Voluntary Sector Quarterly, 31(1), 115-130.

Emerson, E., Graham, H., \& Hatton, C. (2006). The measurement of poverty and socio-economic position in research involving people with intellectual disability. In L. M. Glidden (Ed.), International review of research in mental retardation (pp. 77-108). New York: Academic Press.

Felce, D., \& Perry, J. (1995). Quality of life: Its definition and measurement. Research in Developmental Disabilities, 16, 51-74.

Funnell, S. C., \& Rogers, P. J. (2011). Purposeful program theory: Effective use of theories of change and logic models (Vol. 31). Hoboken: Wiley.

Glenn, J. C. (2014). Our global situation and prospects for the future. The Futurist, 48, 15-25.

Gray, M., Healy, K., \& Crofts, P. (2003). Social enterprise: Is it the business of social work? Australian Social Work, 56(2), 141-152.

International Research Consortium on Evidence-Based Practices. (2013). The organization effectiveness and efficiency scale. Retrieved from www.oeesonline.com.

Isaacs, B., Clark, C., Correia, S., \& Flannery, J. (2009). Utility of logic models to plan quality of life outcome evaluations. Journal of Policy and Practice in Intellectual Disabilities, 6(1), 52-61.

Johnson, S. (2000). Literature review on social entrepreneurship. Toronto: Canadian Centre for Social Entrepreneurship.

Kapucu, N., Healy, B. F., \& Arshan, T. (2011). Survival of the fittest: Capacity building for small nonprofit organizations. Evaluation and Program Planning, 34, 236-245.

Kidd, S. A., \& McKenzie, K. J. (2013). Moving the mental health equity dialogue forward: The promise of a social entrepreneur framework. Administration Policy in Mental Health, 40, 55-57.

Kumar, S., \& Gupta, K. (2013). Social entrepreneurship: A conceptual framework. International Journal of Management and Social Sciences Research, 2(8), 2319.

Lewin, K. (1951). Problems in research in social psychology. In D. Cartwright (Ed.), Field theory in social science (pp. 125-142). New York: Harper \& Brothers.

Light, P. C. (2005). Searching for social entrepreneurs: Who they might be, where they might be found, what they do. In Draft presented at the Conference of the Association for Research on Nonprofit and Voluntary Organizations, November (pp. 17-19).

Linnell, D. (2003). Evaluation of capacity building: Lessons from the field. Washington, DC: Alliance for Nonprofit Management.

Lumpkin, G. T., Moss, T. W., Gras, D. M., Kato, S., \& Amezcua, A. S. (2013). Entrepreneurial processes in social contexts: How are they different, if at all? Small Business Economics, 40, 761-786.

Mair, J., \& Marti, I. (2006). Social entrepreneurship research: A source of explanation, prediction, and delight. Journal of World Business, 41, 36-44.

Manchester, J., Gray-Miceli, D. L., Metcaff, J. A., Paolini, C. A., Napier, A. H., Coogle, C. L., \& Owens, M. G. (2014). Facilitating Lewin's change model with collaborative evaluation in promoting evidence-based practices in health professionals. Evaluation and Program Planning, 47, 82-90.

Montgomery, A. W., Dacin, P. A., \& Dacin, M. T. (2012). Collective social entrepreneurship: Collaboratively shaping social good. Journal of Business Ethics, 111, 375-388. 
Peredo, A. M., \& Chrisman, J. J. (2006). Toward a theory of community-based enterprise. Academy of Management Review, 31(2), 309-328.

Peredo, A. M., \& McLean, M. (2006). Social entrepreneurship: A critical review of the concept. Journal of World Business, 41, 56-65.

Petry, K., Maes, B., \& Vlaskamp, C. (2005). Domains of quality of life of people with profound multiple disabilities: The perspective of parents and direct support staff. Journal of Applied Research in Intellectual Disabilities, 18, 35-46.

Putnam, R. D., Feldstein, L., \& Cohen, D. J. (2004). Better together: Restoring the American community. New York: Simon and Schuster.

Roberts, D., \& Woods, C. (2005). Changing the world on a shoestring: The concept of social entrepreneurship. University of Auckland Business Review, 7(1), 45-51.

Schalock, R. L., Bonham, G. S., \& Verdugo, M. A. (2008). The conceptualization and measurement of quality of life: Implications for program planning and evaluation in the field of intellectual disabilities. Evaluation and program planning, 31(2), 181-190.

Schalock, R. L., Brown, I., Brown, R., Cummins, R. A., Felce, D., Matikka, L., \& Parmenter, T. (2002). Conceptualization, measurement, and application of quality of life for persons with intellectual disabilities: Report of an international panel of experts. Mental Retardation, 40(6), 457-470.

Schalock, R. L., Gardner, J. F., \& Bradley, V. J. (2007). Quality of life for persons with intellectual and other developmental disabilities: Applications across individuals, organizations, communities, and systems. Washington, DC: American Association on Intellectual and Developmental Disabilities.

Schalock, R. L., Lee, T., Verdugo, M. A., Swart, K., Claes, C., van Loon, J., \& Lee, C-S. (2014). An evidence-based approach to organization evaluation and change in human service organizations evaluation and program planning. Evaluation and Program Planning, 45, 110-118.

Schalock, R. L., \& Verdugo, M. A. (2012a). A conceptual and measurement framework to guide policy development and systems change. Journal of Policy and Practice in Intellectual Disabilities, 9(1), $70-79$.

Schalock, R. L., \& Verdugo, M. A. (2012b). A leadership guide for today's disabilities organizations: Overcoming challenges and making change happen. Baltimore: Brookes.

Schalock, R. L., \& Verdugo, M. A. (2013). The transformation of disabilities organizations. Intellectual and Developmental Disabilities, 51, 273-286.

Snell, M. E., \& Luckasson, R. (2009). Characteristics and needs of people with intellectual disability who have higher IQs. Intellectual and Developmental Disabilities, 47, 220-233.

Sterk, E., Specht, M., \& Valraven, G. (2013). Sociaal ondernemerschap in de participatiesamenleving: Van de brave naar de eigenwijze burger. Antwerpen: Garant.

Stone, W. (2003). Bonding, bridging, and linking with social capital. Stronger Families Living Exchange Bulletin, 4, 13-16. Australia.

Thake, S., \& Zadek, S. (1997). Practical people, noble causes. How to support community based social entrepreneurs. London: New Economics Foundation.

Van Loon, J., \& Van Hove, G. (2001). Emancipation and self-determination of people with learning disabilities and down-sizing institutional care. Disability \& Society, 16(2), 233-254.

Weil, M. O. (1996). Community building: Building community practice. Social Work, 41, 481-499.

Zuna, N., Summers, J. A., Turnbull, A. P., Hu, X., \& Xu, S. (2010). Theorizing about family quality of life. In R. Kober (Ed.), Enhancing the quality of life of people with intellectual disability: From theory to practice (pp. 241-278). Dordrecht: Springer. 